\title{
IMPLEMENTASI LESSON STUDY DALAM MATA KULIAH ANALISIS KESALAHAN BERBAHASA UNTUK MENINGKATKAN KEMAMPUAN KOOPERATIF MAHASISWA SEMESTER VII STKIP MUHAMMADIYAH KOTABUMI
}

\author{
Dewi Ratnaningsih *)
}

\begin{abstract}
Abstracs
This article talks about The Implementation of Lesson Study on "Analisis Kesalahan Berbahasa" (Language Error Analysis) subject. The purpose of this research is to describe the implementation of lesson study and to see the effect of increasing cooperative skill of student. Based on the observation, the are some lesson learnt: a) the use of collaborative learning method could give space to student to make discussion, so it could increase student cooperative skill, b) there are intensive discussion on the partial group (consist of 2-4 members. It shows that implementation of lesson study could increase student cooperative.
\end{abstract}

Keyword: Implementation, lesson study, cooperative skill

\section{Pendahuluan}

Lesson study merupakan suatu kegiatan pembinaan guru/dosen untuk meningkatkan kualitas pembelajaran. Kualitas pembelajaran yang dapat ditingkatkan meliputi kualitas guru/pendidik, peserta didik, proses pembelajaran, dan hasil pembelajaran. Lesson study mengutamakan prinsip kolaboratif yang dilakukan secara berkelanjutan. Pelaksanaan Lesson study memungkinkan terbentuknya komunitas belajar sehingga kualitas dari setiap aspek pembelajaran dapat ditingkatkan. Rusman (2101:384) menjelaskan lesson study adalah suatu model pembinaan profesi pendidik melalui pengkajian pembelajaran secara kolaboratif dan berkelanjutan yang berlandaskan pada prinsip-prinsip kolegalitas dan mutual learning untuk membangun learning community. Sudrajat dalam Sandi
(2010:9) mengatakan bahwa "lesson study merupakan salah satu upaya untuk meningkatkan proses dan hasil pembelajaran yang dilaksanakan secara kolaboratif dan berkelanjutan oleh sekelompok guru". Lesson study pertama kali berkembang di negara yang memunyai julukan Negeri Matahari Terbit sejak tahun 1900-an.

Implementasi lesson study sebagaimana yang telah dikembangkan oleh tim JICA (Japan International Corporation Agency) IMSTEP (Indonesian Mathematics and Science Teacher Education Project), yaitu sebuah proyek kerjasama antara tiga perguruan tinggi di Indonesia dengan JICA, merumuskan langkah-langkah lesson study dalam tiga langkah, yang terdiri atas: plan (merencanakan atau merancang), do (melaksanakan), see (mengamati dan sesudah 
itu merefleksi hasil pengamatan). Ketiga Langkah-langkah tersebut dilukiskan dalam kegiatan tersebut diistilahkan sebagai siklus bagan di bawah ini. pengkajian pembelajaran (Susilo, 2009:2).

\section{Plan (perencanaan)}

\section{Do (Pelaksanaan)}

\section{Siklus}

\section{See (Refleksi)}

Rusman (2010:394) mengatakan bahwa manfaat dari lesson study, yaitu:1) meningkatnya pengetahuan guru tentang materi ajar dan pembelajarannya, 2) meningkatnya pengetahuan guru tentang cara mengobservasi aktivitas belajar siswa, 3) menguatnya hubungan kolegalitas baik antarguru maupun dengan observer lain selain guru, 4) menguatnya hubungan antara pelaksanaan pembelajaran sehari-hari dengan tujuan pembelajaran jangka panjang, 5) meningkatnya motivasi guru untuk senantiasa berkembang, dan 6) meningkatnya kualitas rencana pembelajaran termasuk komponenkomponennya seperti bahan ajar, teaching materials (hands on) dan strategi pembelajaran.

Wang-Iverson dan Yoshida dalam Sukirman (2006:7) menyebutkan bahwa manfaat dari lesson study sebagai berikut: 1) mengurangi keterasingan guru (dari komunitasnya), 2) membantu guru untuk mengobservasi dan mengkritisi pembelajarannya,

3) memperdalam pemahaman guru tentang materi pelajaran, cakupan dan urutan materi dalam kurikulum, 4) membantu guru memfokuskan bantuannya pada seluruh aktivitas belajar siswa, 5) menciptakan terjadinya pertukaran pengetahuan tentang pemahaman berpikir dan belajar siswa, dan 6) meningkatkan kemampuan kolaborasi/kooperatif pada sesama pendidik, sesama peserta didik, dan pendidik dan peserta didik.

Lesson study memunyai banyak manfaat, salah satu manfaat dari lesson study, yaitu meningkatkan kemampuan kolaborasi/kooperatif sesama pendidik, sesama peserta didik, dan pendidik dan peserta didik. Berdasarkan hal tersebut, penelitian ini akan memfokuskan implementasi Lesson study terhadap peningkatan kemampuan kooperatif mahasiswa.

Kemampuan merupakan kesanggupan atau kematangan seseorang terkait dengan 
kompetensi dan skill yang diperoleh dari pendidikan, pengalaman, dan pelatihan. Jonhson dalam Apriono (2011:162) menyatakan kooperatif adalah bekerja secara bersama untuk mencapai tujuan yang diinginkan. Berdasarkan pengertian tersebut, dapat disimpulkan kemampuan kooperatif adalah kesanggupan atau kematangan kompetensi dan skill yang digunakan oleh sekelompok orang untuk bekerja secara bersama demi mewujudkan tujuan yang diinginkan. Kemampuan kooperatif sangat diperlukan dalam proses pembelajaran, terutama bagi mata kuliah yang bersifat praktis, salah satunya adalah mata kuliah Analisis Kesalahan Berbahasa.

Analisis kesalahan berbahasa merupakan mata kuliah wajib yang ada di semester VII. Kesalahan berbahasa dari setiap komponen linguistik merupakan materi yang dibahas dalam mata kuliah ini. Tujuan pembelajaran yang diharapkan dari mata kuliah ini, yaitu setelah mempelajari dan mengikuti tutorial mata kuliah ini, mahasiswa diharapkan memahami dan memunyai kompetensi tentang cara menganalisis kesalahan berbahasa.

Salah satu cara untuk mewujudkan tujuan pembelajaran di atas, yaitu perlu direncanakan proses pembelajaran yang berpusat pada mahasiswa (student center). Pembelajaran yang berpusat pada mahasiswa dapat membentuk mahasiswa menjadi lebih aktif dalam proses pembelajaran. Keaktifan mahasiswa di dalam pelaksanaan pembelajaran akan terwujud ketika mahasiswa memiliki kemampuan kooperatif yang mumpuni. Melalui kemampuan kooperatif, mahasiswa dapat bekerja sama untuk menganalisis dan memecahkan permasalahan kesalahan berbahasa. Oleh karena itu, lesson study dapat dijadikan sebagai solusi untuk meningkatkan keaktifan dan kemampuan kooperatif peserta didik (mahasiswa).

\section{Metode}

Metode yang digunakan dalam penelitian ini, yaitu metode deskriptif kualitatif. Metode deskriptif kualitatif menurut Sugiono (2010:15) adalah metode penelitian yang berlandaskan pada filsafat positivisme, digunakan untuk meneliti pada kondisi objek yang alamiah, (sebagai lawannya adalah eksperimen). Peneliti sebagai instrumen kunci, pengambilan sampel sumber data dilakukan secara purposive dan snowbaal, teknik pengumpulan dengan trianggulasi, analisis data bersifat induktif/kualitatif, dan hasil penelitian kualitatif lebih menekan makna daripada generalisasi.

Implementasi lesson study dilakukan pada tanggal 6-13 Oktober 2017, di ruang 1 gedung AR Fahrudin STKIP Muhammadiyah Kotabumi. Mahasiswa yang menjadi subjek penelitian, yaitu mahasiswa semester VII yang berjumlah 19 orang. Namun, tidak 
semua mahasiswa hadir dalam pelaksanaan pembelajaran. Teknik pengumpulan data diperoleh dari hasil observasi dan catatan lapangan yang dilakukan oleh para observer. Data-data dari para observer kemudian dianalisis untuk melihat apakah implementasi lesson study dapat meningkatkan kemampuan kooperatif mahasiswa.

III. Implementasi dan Hasil Implementasi Lesson Study dalam Mata Kuliah Analisis Kesalahan Berbahasa

\section{Implementasi Lesson Study dalam Mata Kuliah Analisis Kesalahan Berbahasa}

Prosedur implementasi lesson study terdiri atas: perencanaan (plan), pelaksanaan (do), dan refleksi (see). Perencanaa merupakan tahap awal yang menentukan keberhasilan proses pembelajaran. Hendayana (2007:11) menyatakan perencanaan bertujuan untuk merancang pembelajaran yang berpusat pada mahasiswa (student center). Hal ini berarti setiap tindakan pembelajar dalam proses pembelajaran diarahkan pada keaktifan mahasiswa. Plan dalam lesson study merupakan proses perencanaan yang dilakukan secara kolaboratif.
Perencanaan pembelajaran diawali dengan proses pengidentifikasian hal-hal terkait materi yang akan dibahas, metode atau cara yang digunakan, dan penilaian yang digunakan dalam proses pembelajaran. Selanjutnya dosen model dan beberapa observer memerinci dan menyesuaikannya berdasarkan alokasi waktu yang digunakan. Hasil dari pengidentifikasian dan penganalisisan tersebut adalah lesson design. Lesson design dibuat disetiap pertemuan, yang selanjutnya kumpulan lesson design tersebut membentuk lesson plan.

Lesson design mata kuliah Analisis Kesalahan Berbahasa dirancang oleh dosen model dan tiga orang observer. Lesson design pada pertemuan pertama dibahas tentang materi kesalahan berbahasa tataran fonologi. Metode yang digunakan, yaitu learning together dan penilaian yang digunakan, yaitu tes lisan dan tulisan. Perincian dari materi berdasarkan alokasi waktu, yaitu 20 menit untuk pembukaan, 50 menit untuk kegiatan inti, 20 menit untuk pemberian tugas, dan 10 menit untuk penutup. Perincian tersebut sesuai dengan alokasi waktu untuk mata kuliah Analisis Kesalahan berbahasa, yaitu 2 SKS atau 100 menit. Lesson design secara lengkap terdapat pada gambar di bawah ini. 


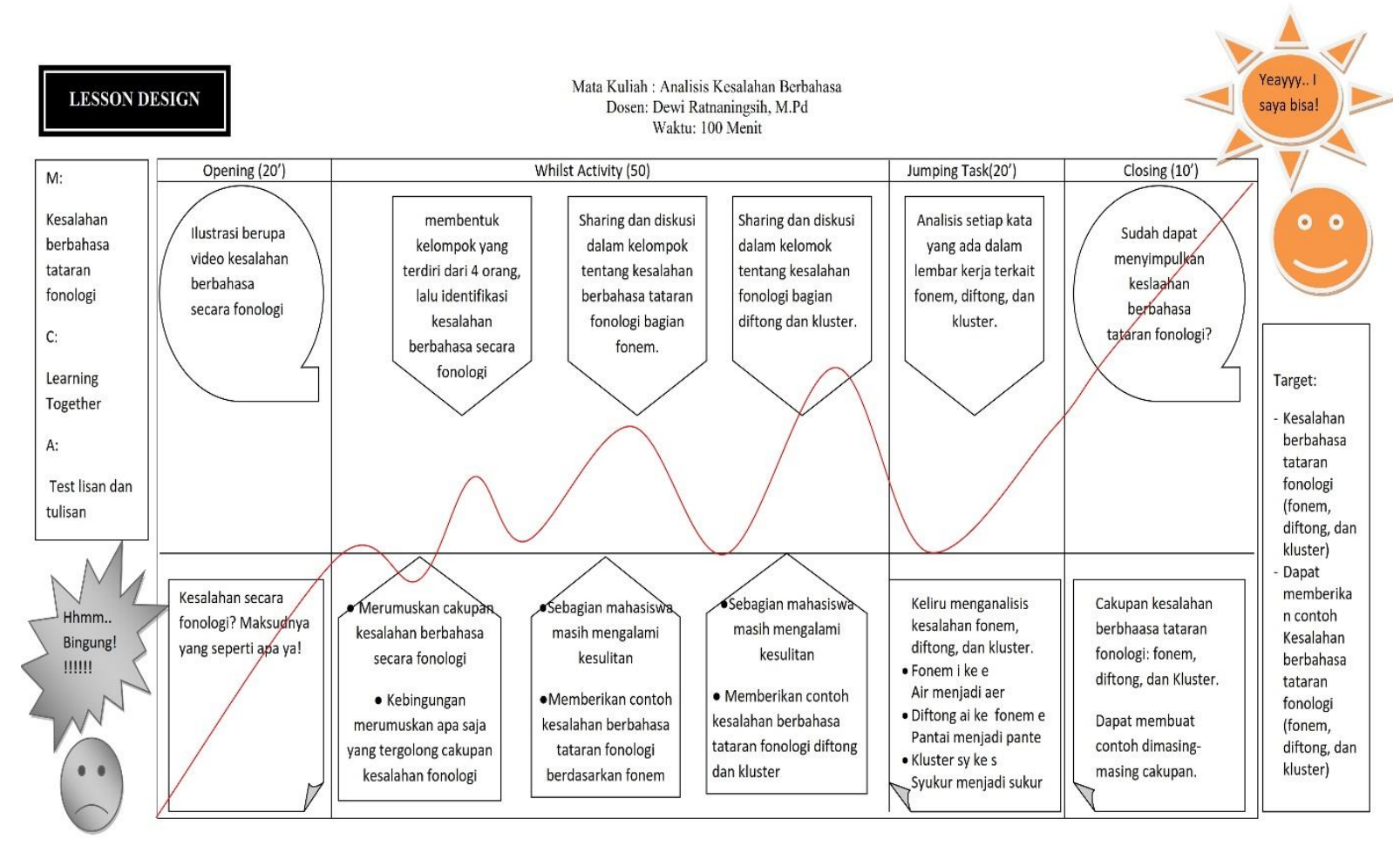

Tahap setelah perencanaan (plan) adalah pelaksanaan $(\mathrm{do})$ pembelajaran. Proses do merupakan penerapan dari plan. Hal-hal yang telah direncanakan dalam plan direalisasikan. Dosen model merupakan aktor yang berperan dalam pelaksanaan pembelajaran. Dosen model merealisasikan skenario pembelajaran yang telah dibuat, sementara dosen lain bertindak selaku observer yang mengamati proses pembelajaran. Observer akan mengamati dan mencatat setiap tindakan yang dilakukan oleh mahasiswa.

Tahap pelaksanaan (do) pembelajaran dalam mata kuliah Analisis Kesalahan Berbahasa dilakukan oleh Dewi Ratnaningsih sebagai dosen model dan tiga orang dosen sebagai observer. Tahap do diawali dengan pemberian tayangan video terkait kesalahan berbahasa tataran fonologi. Pemberian video dimaksudkan untuk menstimulus mahasiswa terkait kesalahan berbahasa tataran fonologi yang terjadi di lingkungan sekitar. Setelah mahasiswa melihat tayangan video, mahasiswa membentuk kelompok yang terdiri atas 4 anggota. Setiap kelompok mendiskusikan hal-hal terkait kesalahan berbahasa tataran fonologi, yakni: fonem, diftong, dan kluster.

Pembagian kelompok dimaksudkan untuk mengasah dan meningkatkan kemampuan kooperatif mahasiswa. Mahasiswa bekerja sama untuk menyelesaikan permasalahan berbahasa 
tataran fonologi. Diawal kegiatan inti, menyampaikan hasil temuan dari proses mahasiswa diberi kesempatan untuk berdiskusi dan bekerjasama menyelesaikan pengamatan.

Proses refleksi mata kuliah Analisis kesalahan berbahasa tentang fonem. Kesalahan berbahasa tentang fonem yang dibahas berupa kesalahan karena perubahan, penghilangan, dan penambahan fonem. Dilanjutkan dengan materi diftong dan kluster. Setiap pemberian materi akan diberikan "tantangan" sehingga jumlah tantangan sesuai dengan materi yang diberikan.

Sebelum memasuki tahap akhir pembelajaran, dosen model memberikan "jumping task" (lompatan tugas). Jumping task merupakan pemberian tugas yang tingkat kesulitannya melebihi tantangan yang diberikan sebelumnya. Pemberian jumping task dimaksudkan untuk memotivasi dan membuat mahasiswa lebih intens bekerjasama dengan rekan sekelompoknya. Jumping task yang diberikan dosen model berupa lembaran tugas yang berisi studi kasus terkait kesalahan berbahasa tataran fonem, diftong, dan kluster.

Tahap terakhir setelah plan dan do adalah see. See (refleksi) merupakan kegiatan melihat gambaran proses pembelajaran yang telah dilakukan. Proses refleksi dilakukan secara bersama. Dosen model mengawali proses refleksi dengan memberikan penjelasan terkait hal-hal yang terjadi dalam pelaksanaan pembelajaran. Selanjutnya diikuti oleh para observer yang disampaikan tidak relevan dengan 
pertanyaan. 2) kelompok dua belum secara aktif berdiskusi bersama. Dari tiga anggota kelompok, hanya satu, yaitu Kesih yang aktif untuk menjelaskan kepada aggota kelompok yang lain. Dua anggota kelompok hanya mendengar dan tidak memberikan respon aktif, seperti bertanya atau menyanggah pernyataan yang dikemukakan oleh Kesih.3), kelompok tiga terlihat terlalu bersemangat atau antusias dalam proses pembelajaran. Antusiasme kelompok tiga terlihat dari baiknya respon yang ditunjukkan oleh setiap anggota kelompok. Terlalu bersemangatnya anggota kelompok tiga dalam menjawab pertanyaan terkadang membuat jawaban yang dikemukakan keliru.

Hasil pengamatan observer kedua, yaitu: 1) di awal perkuliahan, observer dua mencatat hanya satu orang di setiap kelompok yang aktif melaksanakan diskusi. Namun, dipertengahan pembelajaran mulai terjadi pemerataan keaktifan mahasiswa.2) di kelompok dua, terdapat salah satu anggota kelompok yang terlihat kurang termotivasi dalam proses pembelajaran. Kurangnya motivasi mahasiswa terlihat dari kurangnya mahasiswa berbaur dalam proses diskusi. 3) sama halnya dengan observer pertama, observer kedua mencatat hal yang sama terkait aktivitas kelompok tiga. Kelompok tiga termasuk kelompok yang terlihat sangat antusias. Antusiasme anggota kelompok terlihat dari cepatnya menjawab pertanyaan. Namun, jawaban yang disampaikan selalu salah. Tergesa-gesanya anggota kelompok membuat proses menjawab tidak dipikirkan secara mendalam sehingga jawaban menjadi salah.

Hasil pengamatan observer ketiga, yaitu: 1), observer tiga mencatat aktivitas di kelompok satu yang terlalu antusias. Kelompok satu ingin cepat menyelesaikan dan menjawab tantangan. Namun. karena terlalu ingin cepat selasai membuat jawaban yang dihasilkan manjadi salah. 2) observer ketiga mencatat baiknya keaktifan yang ditunjukkan oleh setiap kelompok. Setiap anggota kelompok terlihat sengat bersemangat mengikuti pembelajaran sehingga keaktifan dari setiap anggota kelompok sangat terlihat.

\section{Hasil Implementasi Lesson Study dalam Mata Kuliah Analisis Kesalahan Berbahasa}

Catatan dari para observer merupakan indikator yang dapat dijadikan bahan perbaikan proses pembelajaran. Hasil pengamatan dari para observer yang telah dikemukakan di atas, menghasilkan sebuah lesson learn dari implementasi lesson study dalam mata kuliah Analisis Kesalahan Berbahasa. Lesson learn yang diperoleh dari satu siklus di atas, yaitu a) pemberian media pembelajaran yang bersifat audio visual di awal pembelajaran dapat membangun motivasi dan membuka pikiran mahasiswa terkait materi yang akan dipelajari, b) 
penggunaan metode pembelajaran yang bersifat kolaborasi membuka ruang bagi mahasiswa untuk berdiskusi sehingga dapat meningkatkan kemampuan kooperatif mahasiswa, c) kelompok-kelompok kecil (teridri atas 2-4 anggota), memungkinkan terjadinya diskusi secara intens sehingga dapat meningkatkan kemampuan kooperatif mahasiswa.

\section{Simpulan}

Berdasarkan hasil pengamatan yang dilakukan oleh para observer, dapat dikatakan bahwa lesson study memengaruhi proses pembelajaran yang terjadi dalam mata kuliah Analisis Kesalahan Berbahasa. Pengaruh yang diberikan mengarah pada peningkatan kualitas pembelajaran, terutama peningkatan kualitas kemampuan kooperatif mahasiswa. Selama proses pembelajaran berlangsung, mahasiswa terlihat aktif dan mendominasi kegiatan pembelajaran. Para observer dan dosen model sepakat bahwa setiap anggota kelompok mampu bekerjasama dengan baik.

\section{Daftar Rujukan}

Apriono, Djoko. 2011. Meningkatkan Keterampilan Kerjasama Siswa Dalam Belajar Melalui Pembelajaran Kolaboratif. Online. (http://ejournal.unirow.ac.id/ojs/files /journals/2/articles/4/public/8.\%20joko .pdf, diakses tanggal 21 Oktober 2017)

Hendayana, Sumar. 2007. Lesson Study, Suatu Strategi Untuk Meningkatkan
Keprofesionalan Pendidik (Pengalaman IMSTEP-JICA). Bandung: UPI Press.

Rusman. 2010. Model-Model Pemebelajaran Mengembangkan Profesionalisme Guru. Bandung: Raja Grafindo Persada.

Sandi. 2010. Pengembangan Bahan Workshop Lesson study Serta Implementasi Oleh Guru Matematika di Madrasah Ibtidaiyah Negeri 1 Pangkalpinang. Tesis tidak diterbitkan. Palembang: Fakultas Keguruan dan Ilmu Pendidikan.

Sugiono. 2010. Metode Penelitian Kuantitatif Kualitatif Dan R\&D. Bandung: Alfabeta.

Sukirman. 2006. Peningkatan Keprofesionalan Guru Melalui Lesson study. Makalah disajikan dalam Pelatihan Lesson study Bagi Guru Berprestasi dan MGMP MIPA SMP Seluruh Indonesia, Yogyakarta, 26 November-10 desember 2006.

Susilo, Herawati. 2009. Lesson study Berbasis Sekolah" Guru Konservatif Menuju Guru Inovatif”. Malang: Bayumedia Publishing. 